\title{
New Hope for Corporate Governance in China?
}

James V. Feinerman

Georgetown University Law Center, feinerma@law.georgetown.edu

Copyright @ 2007 Cambridge University Press; http://journals.cambridge.org/action/ displayJournal?jid=CQY

This paper can be downloaded free of charge from:

https://scholarship.law.georgetown.edu/facpub/589

2007 China Q. 590-619

This open-access article is brought to you by the Georgetown Law Library. Posted with permission of the author. Follow this and additional works at: https://scholarship.law.georgetown.edu/facpub

Part of the Business Organizations Law Commons, and the International Law Commons 


\title{
New Hope for Corporate Governance in China?
}

James V. Feinerman

\begin{abstract}
China's recent revisions to its Company Law and Securities Law have brought new attention to issues of corporate governance in Chinese companies and financial markets. Among the chief criticisms of the earlier laws - in both their provisions and application - were the lack of protection for minority shareholders, the paucity of independent directors, the absence of transparency and inadequate financial disclosure. The acknowledged need for greater congruence between Chinese law and practice and that of countries with more developed capital markets led to the proposal of amendments to China's legislation during the first half of this decade. This article highlights several improvements resulting from the revisions as well as remaining weaknesses in the regulatory framework for corporate enterprises in China.
\end{abstract}

Corporate governance, gongsi zhili (公司治理) has become an increasingly important topic in academic, business and policy discussions in China in the last few years. It is closely related to ongoing economic reform, especially of stateowned enterprises (SOEs), and development of the securities and financial market. Recent revisions of China's Company Law and Securities Law have focused new attention on various aspects of corporate governance, including shareholder voting rights and fiduciary duties. These laws will determine the proper roles of a corporate board and its directors, the rights of shareholders, the fiduciary duties of directors and officers, and the balance between directors' responsibilities and the reasonable protection of directors. While it was not the primary goal in their revision, in their current form they hold out some promise for improving corporate governance in China. Of potentially larger significance are changes they imply for other arenas of life and politics there.

How is corporate governance important for China? Better corporate governance is a vital link in bringing capital to China; affordable capital creates jobs, increases tax revenue, increases shareholder wealth - all leading to an increase in the standard of living. Full disclosure and transparency also serve to promote good corporate governance and capital mobility. In China today it is not possible for any sizeable enterprise to ignore the ramifications of globalization and implications for corporate governance. But there is a conundrum: looking at China, and what it has been able to achieve with relatively poor corporate governance, is there still an argument for a good, or at least better, system? China may present a unique "high risk-high reward" 
scenario in global corporate governance, with a singular combination of 1.3 billion people, vast resources and economic momentum. Yet the emphasis on the acquisition and deployment of capital raises a question with some salience for China. What makes capital "unaffordable"? In China's case, there are several countervailing forces: scarcity due to policy loans made to underperforming state-owned enterprises; corruption premiums ranging from 20 per cent to as high as 50 per cent for non-transparency ${ }^{1}$; and the basic fact that global demand for capital is greater than the supply.

While there are many factors which influence corporate governance, several important pillars include respect for (and legal protection of): a wide range of stakeholders in the enterprise; the board of directors and its responsibilities; disclosure and transparency; and the rights of shareholders, including their equitable treatment. Yet the essence of corporate governance is doing the right thing whether or not anyone is watching; not doing it because the law says so, but doing it because it's right. Of course, good corporate governance also promotes increased regional and international recognition for Chinese corporations and overall greater prosperity.

As a practical matter, however, there must be incentives to change. For Chinese enterprises, these may include an increasing perception of better performance, higher earnings, more access to affordable capital, reduced tension among stakeholders and other benefits. Legal adjustments may also lead to less government interference with the market mechanisms, which in turn builds trust and confidence by the stakeholders, who will then contribute money, talent and greater vitality to civic life.

This article begins by trying to define (generically and in the Chinese context) corporate governance. A few particular Chinese issues are highlighted, including board issues, shareholders' issues, transparency and disclosure, and monitoring. The article also attempts some preliminary evaluation of the effectiveness of the recently revised Chinese Company Law and Securities Law in dealing with these corporate governance questions.

1 Transparency International, National Integrity System, Transparency International Country Study Report, China 2006: "As China is in the process of unprecedented reform and transition in its economic, political and social systems and a proper legal anti-corruption framework is yet to develop, there are still huge opportunities for corruption. Corruption remains a big challenge in China. ... Overregulation of the economy has impeded the private sector and civil society. Extra-budgetary funds provide opportunities for corruption, and government transparency is limited" (http://www. transparency.org/policy_research/nis/regional/asia_pacific China_nis_2006.pdf, p. 8). Cf. Bernard Black, "The corporate governance behavior and market value of Russian firms," Emerging Markets Review, Vol. 2, No. 2 (2001), pp. 89-108. (Study of Russian firms showed that a worst-to-best improvement in corporate governance predicted an astronomical 700 -fold $(70,000 \%)$ increase in firm value!) See also International Finance Corporation, "The irresistible case for corporate governance," March 2006, http://www.ifc.org/ifcext/pepse.nsf/AttachmentsByTitle/IrresistibleCase4CG.pdf/\$FILE/ IrresistibleCase4CG.pdf. 


\section{Defining Objective Corporate Governance Standards}

Corporate governance relates to the internal means by which corporations are operated and controlled. In the formulation of the Organization for Economic Co-operation and Development (OECD), an international organization of developed countries that accept the principles of representative democracy and a free market economy:

Corporate governance is the system by which business corporations are directed and controlled. The corporate governance structure specifies the distribution of rights and responsibilities among different participants in the corporation, such as the board, managers, shareholders and other stakeholders, and spells out the rules and procedures for making decisions on corporate affairs. By doing this, it also provides the structure through which the company objectives are set, and the means of attaining those objectives and monitoring performance.

The corporate governance principles of the $\mathrm{OECD}^{2}$ are recognized as an influential, objective set of corporate governance principles and represent the first initiative by an inter-governmental organization to develop the core elements of a good corporate governance regime. The principles can be used as a benchmark by governments as they evaluate and improve their laws and regulations. They have also been used by private sector parties that have a role in developing corporate governance systems and best practices.

The OECD principles comprise five themes: protection of shareholders' rights; equitable treatment of all shareholders, including minority and foreign shareholders; recognition of the rights of stakeholders as established by law; ensuring timely and accurate disclosure of all material matters regarding the corporation; and effective monitoring of management by the board, with board accountability to the company and the shareholders. Each of these principles has salience for the current situation in China, since every one of them has proven problematic since the inception of China's corporatizing reforms over the past two decades.

\section{General Observations on Corporate Governance in China}

Since China's first Company Law, ${ }^{3}$ enacted in 1993 to come into effect in 1994, much has been accomplished in establishing the basic features of corporate governance; however, there is still much to do. While various laws had existed before the Company Law to deal with state, collective and private enterprises and those with foreign investment, the Company Law was the first attempt since 1949 to create limited liability companies without regard to the nature of

2 Available at http://www.oecd.org/dataoecd/32/18/31557724.pdf.

3 The Company Law of the People's Republic of China, Zhonghua renmin gongheguo gongsi fa, adopted by the Fifth Session of the Standing Committee of the Eighth National People's Congress, 29 December 1993, effective 1 July 1994; revised at the 18th Meeting of the Standing Committee of the Tenth National People's Congress, 27 October 2005, according to the Decision on Revising the Company Law of the People's Republic of China, at the 11th Meeting of the Standing Committee of the Tenth People's Congress, 28 August 2004. 
ownership as part of a modern economic system. ${ }^{4}$ In little more than a decade, corporate governance has moved to the centre stage of Chinese enterprise reform. The Fourth Plenum of the Chinese Communist Party's 15th Central Committee held in September 1999 adopted a decision that identified corporate governance as the core of the modern enterprise system. Commitments under the World Trade Organization add some urgency to tackle corporate governance issues in a comprehensive and systematic manner. ${ }^{5}$

However, the current legal framework - even after the recent revisions of the Company $\mathrm{Law}^{6}$ and the Securities $\mathrm{Law}^{7}$ - still provides rather limited shareholder protection. In the light of continuing majority government ownership of enterprises, corporations with concentrated ownership still predominate. Small shareholders are inactive in company oversight; government influences management appointments and corporate operations. Too much power remains concentrated in the hands of a few shareholders, and there is - in many instances - a lack of accountability for corporate actions or omissions.

\section{Major issues of corporate governance in Chinese listed companies}

The biggest single factor affecting corporate governance in China is state ownership: the Chinese state owns about 50 per cent of all the shares of listed companies. Moreover, during the economy's transition from command to market it is often unclear who represents the state as a shareholder in the listed companies. In addition, transactions between the controlling shareholder (or a group company) and the listed company often disadvantage minority shareholders.

Other issues for corporate governance relate to the directors and officers of Chinese listed companies. For example, most directors are "inside" or executive directors; few companies have many independent directors, leading to insider control. Although Chinese securities regulators attempted to overhaul insider-

4 But see James Feinerman, "Backwards into the future (Securities Law in the People's Republic of China)," Law and Contemporary Problems, Vol. 52, No. 3 (1989) pp. 169-84, describing institutions in existence before the enactment of enabling legislation such as the 1994 Company Law and 1999 Securities Law.

5 A study based on empirical evidence and survey data on Shanghai's publicly listed companies concluded that China's approach to corporate governance development may be failing to achieve its objectives and outcomes. These data - gathered before Chinese accession to the WTO - showed the adoption of Anglo-American external market-based models: i.e. a top-down legalistic approach to mandate formal corporate governance structures as the major means to develop modern corporate forms. It remains to be seen whether the problem lies in choosing the wrong model or incomplete implementation of the model chosen. O.K. Tam, "Models of corporate governance for Chinese companies," Corporate Governance: An International Review, Vol. 8, No. 1 (2000), pp. 52-64.

6 Revised for the third time at the 18th Session of the Tenth National People's Congress, 27 October 2005.

7 The Securities Law of the People's Republic of China, Zhonghua renmin gongheguo zhengquan fa, adopted at the Sixth Meeting of the Standing Committee of the Ninth National People's Congress, 29 December 1998, effective 1 July 1999; revised at the 18th Meeting of the Standing Committee of the Tenth National People's Congress, 27 October 2005 according to the Decision on Revising the Securities Law of the People's Republic of China, at the 11th Meeting of the Standing Committee of the Tenth People's Congress, 28 August 2004. 
controlled boards by requiring every listed company to have independent directors forming at least a third of the board, majority power remains extremely concentrated.

Traditionally, executives of PRC companies and other enterprises have been underpaid. ${ }^{8}$ Managers of major listed SOEs, still chosen by the government, are often appointed more for political reliability than managerial skill. ${ }^{9}$ Lack of a market for professional managers and proper incentives for rewarding performance also influence the quality of management. ${ }^{10}$ Information disclosure in many cases is not timely and accurate, and not easily understandable to investors, making it difficult to monitor board and management performance.

\section{The increasing importance of corporate governance reform in China}

An overview of China's securities market shows that in December 2006 there were 1,461 companies listed in China. ${ }^{11}$ There are two stock exchanges, the Shanghai Stock Exchange and the Shenzhen Stock Exchange, both established in 1990. Total market capitalization reached US\$520 billion at the end of 2001, and about US\$516 billion by the end of 2002; at the end of 2006, the Shanghai Stock Exchange's capitalization alone was US\$915 billion. There were over 65 million investor accounts ( 5 per cent of the population), 118 securities firms and dozens of fund management firms in China as of mid-2003. ${ }^{12}$

As for the regulatory system, the China Securities Regulatory Commission (CSRC), established in 1992, oversees all the securities business activities in China (including futures). Its headquarters are in Beijing, with 36 regional offices in each province and many major municipalities, and 1,500 employees. The original Securities Law, enacted in July 1999 and significantly amended in 2005 along with the revised Company Law, provides a legal framework for securities regulation. The CSRC's recent and ongoing measures to improve corporate governance include encouraging public companies to get independent

8 Oliver Rui, Michael Firth and Peter Fung, "Corporate governance and CEO compensation in China" (September 2002). Available at SSRN: http://ssrn.com/abstract=337841.

9 Despite attempts to export Western management techniques and training, it has been suggested that the nature of management tasks and the skills required to run Chinese enterprises may entail different learning. Sue Newell, "The transfer of management knowledge to China: building learning communities rather than translating Western textbooks?" Education \& Training, Vol. 41, No. 67 (1999), pp. 28-29.

10 While in many cases in other countries the primary problem is excessive executive compensation, in China the opposite problem may be more significant: under-compensation of senior managers which would provide a greater incentive to maximize returns for all shareholders. Takao Kato and Cheryl Long, "Executive compensation, firm performance, and corporate governance in China: evidence from firms listed in the Shanghai and Shenzhen Stock Exchanges," IZA Discussion Papers 1767, Institute for the Study of Labor (IZA) (2005).

11 China Securities Regulatory Commission, Statistical Information, http://211.154.210.238/en/statinfo/ index_en. China Enterprise Confederation and China Enterprise Directors Association, China Top 500 Enterprises 2006 Analysis Report, revealed that 349 enterprises were state owned, nearly $70 \%$ of the total. Their combined assets reached 39 trillion yuan (US $\$ 4.87$ trillion) at the end of $2005,95 \%$ of the total. The state-owned economy remains dominant and controls the leading industries in the national economy. 2 September 2006 http://news3.xinhuanet.com/english/2006-09/02/content_5040531.htm.

12 OECD, "China’s securities market," http://www.oecd.org/dataoecd/5/32/18469881.pdf. 
directors on board, to adopt a Code of Corporate Governance and to provide better information disclosure. Legal reform protecting shareholder rights through lawsuits, accounting reform and supervision of auditors have also been promoted by the CSRC.

As noted above, one of the chief policies of CSRC regulation was to increase the number of independent directors to company boards. ${ }^{13}$ By 30 June 2002, 2,414 independent directors had been elected and appointed by shareholder meetings of listed companies. In a survey of 1,084 firms, 80 per cent appointed two independent directors to their board of directors, and 70 per cent had at least one accounting professional as an independent director. ${ }^{14}$

In 2001, just as the United States was beginning to experience the collapse of a series of corporations from Enron to WorldCom to Global Crossing as a result of corporate governance failures, the exposure of several major Enron-type scandals highlighted the urgency of corporate governance reform in China. The companies involved were leading enterprises and their stock prices performed extremely well before they collapsed. It turns out that profit figures were highly inflated or even fabricated by the directors and management to support the high stock prices and for the purpose of secondary offerings. Subsequent abuses from just one year (2004) included the implosion of the conglomerate D'Long group, the arrest of the chairman and six senior executives of Guangdong Kelon Electrical Holdings for overstating revenues and profits by over 2 billion yuan and a three-year prison sentence for one of China's richest citizens, Zhou Zhengyi, for manipulating share prices and falsifying the registered capital of his company, Nongkai Development Group. Zhou's case also proved an embarrassing setback for the Bank of China's then-recently listed Hong Kong branch and revealed internal-control and governance lapses in the Bank of China Hong Kong branch. ${ }^{15}$

In mid-2006, Guangdong Securities Co. was liquidated after the CSRC lifted its business permit and ordered its closure because of "severe irregularities." The CSRC assigned the China Securities Investors Protection Fund the task of trusteeship and liquidation of Guangdong Securities after share transactions were halted on 4 November 2005. Guangdong Securities was the fifteenth

13 Donald Clarke, "The independent director in Chinese corporate governance," Delaware Journal of Corporate Law, Vol. 36, No. 1 (2006) pp. 125-228.

14 See also "China issues new guidelines for listed companies," www.chinaview.cn, 21 March 2006. The China Securities Regulatory Commission (CSRC) issued amended guidelines for the charters of listed companies, first published in 1997. The new guidelines seek to improve corporate governance by limiting the power of executives in order to prevent power abuse or fraudulent transactions. It states that the highest authority in a listed company is the shareholders' meeting, not the board chairman, and that any major decisions must be approved by the shareholders' meeting. Senior managers and employees' representatives must not account for more than half of the directors. Shareholders cannot vote on transactions in which they are involved, and only the shareholders' meeting can appoint accounting firms. Board members, supervisors and senior executives were formerly banned from selling their shares during their tenure. Now they are allowed to sell them one year after the stocks are listed or six months after termination of service. In any given year, they cannot sell more than $25 \%$ of their shares.

15 M. O’Neill, "Shame and scandal on the road to riches," South China Morning Post, 7 August 2006. 
securities firm the CSRC had shut down since August 2004, when it launched a nationwide campaign to crack down on irregularities in the country's problemplagued securities sector "to protect legitimate rights of investors and creditors." 16

Even before some of these occurrences, a Code of Corporate Governance for Listed Companies in China had been developed and enforced from January 2002. The Code is mandatory for all listed companies and has been melded into the listing rules of the two stock exchanges. It stipulates the rights and responsibilities of shareholders, directors, the management and stakeholders. ${ }^{17}$ In addition, information disclosure is an ongoing responsibility of all the listed companies. All the shareholders have an equal right to receive correct, timely and complete information, and regular disclosure of audited annual reports, mid-year reports and unaudited quarterly reports. Disclosure of corporate governance practices is required in the annual report, along with disclosure of information on the controlling shareholder or the actual controller of the company. $^{18}$

Legal and accounting reform has also been coming to China. ${ }^{19}$ Lawsuits have been brought against directors and management. The Supreme People's Court issued provisions in 2001 about procedures for shareholders suing directors and management for losses due to false company disclosure, and the courts have started to accept such cases. Chinese accounting standards are being revised according to international accounting standards. ${ }^{20}$ The regulators have strengthened the supervision of auditors, even revoking the licence for the securities business of one of the largest auditing firms in China because of its involvement in a scandal.

Stronger enforcement of existing law and regulations has led to more regular on-site inspection of listed companies concerning accounting, disclosure, relatedparty transactions and so on. In a given year about 300 firms go through regular inspection; special inspection on compliance with the Code of Corporate Governance has also been enacted. Stronger sanctions include public criticism against violations of laws and regulations; stock exchanges have been given the

16 Xinhua "Liquidation going on with Guangdong Securities Co.," http://english.people.com.cn/200511/ 08/eng20051108_219901.html.

17 CSRC, "Code of corporate governance for listed companies in China," 7 January 2001 (Zhengianfa No.1 of 2002). Available in English at http://www.csrc.gov.cn.

18 Yet as Benjamin Liebman has pointed out, the Chinese media, including the business press, often fail to provide an independent source of information despite some de facto autonomy. Commercialization of the media may create conflicting pressures to highlight sensational cases of abuse and at the same time to suppress unfavourable information about potential advertisers and locally important enterprises. Liebman, "Watchdog or demagogue? The media in the Chinese legal system," Columbia Law Review, Vol. 105, No. 1 (2005), pp. 1-157.

19 Jason Z. Xiao, Yikuan Zhang and Zhihua Xie, "The making of independent auditing standards in China," Accounting Horizons, Vol. 14, No. 1 (2000), p. 69.

20 Nevertheless, studies have found that China's efforts to improve auditing standards were resisted by companies that prefer small local auditors whose political connections may be helpful in gaining regulatory approvals. Qian Wang, T.J. Wong and Lijun Xia, "State ownership, institutional environment and auditor choice: evidence from China" (September 2005), http://www.baf.cuhk.edu. hk/research/cig/pdf_download/WangWongXia.pdf. 
power to reprimand listed companies publicly for violations of their listing rules. The CSRC has also established a joint Bureau for Investigation of Securities Crimes with the Ministry of Public Security to prosecute violations of the Securities Law. ${ }^{21}$

Training of directors and investor education is also a focus of recent reforms. Monthly classes for independent director candidates in Shanghai and Beijing train about 5,000 candidates during a typical year. Monthly training courses for existing directors were organized by the two stock exchanges in 2003 to train all directors over three years. The CSRC also sponsors investor education sessions in major cities and through the media, including the internet.

\section{Key Areas for Reform}

Comparison of the Chinese market with mature global markets suggests a need for more reform of the system of state asset management to broaden ownership structures and to transform the enterprise management techniques employed by the government from administrative fiat to contract. Easier prospects for listing non-state controlled companies and better procedures for mergers and acquisitions would also be welcome. Regardless of their ownership, listed companies need increased incentives for their management, to expand the management talent pool in China by providing more effective compensation schemes.

\section{Concentrated ownership ${ }^{22}$}

In recent years, the three largest shareholders held, on average, about 58 per cent of total shares in listed Chinese companies. In almost half of all firms, the three largest shareholders accounted for 60 to 80 per cent of total shares. In PRC listed companies, the largest shareholder accounts for slightly less than 50 per cent of all shares but controls more than 50 per cent of board seats. Directly or indirectly, the state selects almost 70 per cent of directors of all PRC listed companies. Other jurisdictions recognize a duty of fair dealing by majority shareholders in relation to minority shareholders. Until the most recent reform (and perhaps even afterwards), fiduciary duties of controlling shareholders have not been clearly stipulated in relevant law, and their liabilities for losses incurred by minority shareholders are not obvious.

Recent PRC regulations may introduce this principle implicitly, however, without spelling out liabilities, penalties or the procedures for invoking them.

21 The CSRC has been quick to impose fines under the new Securities Law, which came into effect on 1 January 2006. Maximum fines are between 300,000 and 600,000 yuan. More specifically, in early July 2006, Kelon was fined 600,000 yuan (US\$75,000) for providing false information and other offences; its former chairman, Gu Chujun, was fined 300,000 yuan (US\$37,500) in mid-July 2006 for a number of "economic crimes."

22 Grace Hu and Marc Goergen, "A study of ownership concentration, control and evolution of Chinese IPO companies," available at SSRN: http://ssrn.com/abstract=286612. 
Thus, there continue to be documented abuses by controlling shareholders: taking out soft loans from listed companies on a long-term basis; using listed companies as guarantors for bank loans; and selling assets at unfair prices, usually without an appraisal by an independent evaluator. As noted below, the recently revised Company Law attempts to address these abuses.

\section{Board issues}

In general, Chinese directors are insulated from responsibility for their company's economic performance. Their compensation is not linked to it, and they cannot be dismissed prior to the expiration of their terms without "cause," although what constitutes "cause" is not defined. Directors owe duties of good faith and due diligence and care towards the company and its shareholders, although the law does not define these concepts further or create enforcement mechanisms. Compared with practices in other markets, Chinese boards have less decision-making power within the existing legislative framework, while government ministries and commissions, as well as securities regulatory authorities, have substantial decision-making power. Indeed, the range of decisions which must be made by the shareholders' meeting is extraordinarily large by comparison with the corporate law of other jurisdictions, and the discretion left to the board correspondingly narrow.

The Company Law does not stipulate any disclosure obligation on the part of directors or any specific liabilities for directors who fail to perform their obligations. On 16 August 2001 the CSRC issued the Establishment of Independent Director Systems by Listed Companies Guiding Opinion (the Guiding Opinion), requiring that one-third of Board directors be independent. A 1999 survey showed that only about 3 per cent of all directors had some degree of independence; in 2003, following issuance of the Guiding Opinion, the average company still had only three independent directors. ${ }^{23}$ Moreover, most listed Chinese companies have no system for establishing board committees, and only a few plan to establish them. Companies that do have them usually have an investment or finance committee, an audit committee, a financial management committee, and/or a strategy committee. They lack nominating committees for directors and corporate governance committees; listed companies do not disclose their procedures for nominating directors or their corporate governance principles. The main functions of the committees that do exist are to decide on major investment projects. Independent committees with supervisory and auditing functions are at an early stage of development. Thus, independent directors would have few opportunities to exercise their independent judgement.

23 Cf. Tong Lu, "Development of system of independent directors and the Chinese experience," http:// www.cipe.org/china/development.htm. The author suggests companies facing the new rules established by the CSRC were seeking methods for nominal compliance without implementing the system completely. 


\section{Shareholders' issues}

The Company Law requires every company to hold an annual shareholders' general meeting. While every shareholder may attend a general meeting, recent data indicate that most attendees are state representatives and representatives of legal persons. Not all companies comply with this requirement, and there are indications that some boards simply ignore the meeting's decisions. Shareholders' general meetings sometimes check decisions with the board before taking action. Anecdotal evidence suggests that only about 20 per cent of company actions are voted upon at the shareholders' general meeting, despite the very wide range of situations in which such a vote seems to be legally required.

A major disincentive for shareholder protection is the fact that the Supreme People's Court allows courts to hear only a very limited class of securities-related claims as class actions. ${ }^{24}$ The remedy the Company Law provides to minority shareholders is application to the courts to prevent the continuation of unlawful conduct by directors and majority shareholders. Existing laws and regulations do not specify penalties for corporations and officers that obstruct shareholders' rights to access information. The Securities Law is unclear as to when and whether investors can take civil action against directors and investment professionals for false or negligent disclosures that result in losses.

On 26 December 2002, the Supreme People's Court promulgated the Several Provisions on Trial of Civil Damages Cases Arising from Misrepresentation in the Securities Market (the Provisions), ${ }^{25}$ which entered into effect on 1 February 2003. The Provisions extend the Notice on Questions Concerning the Acceptance of Civil Tort Dispute Cases Arising from Misrepresentation in the Securities Market, ${ }^{26}$ issued and effective on 15 January 2002. The Provisions discuss acceptance of cases and jurisdictions, methods of bringing lawsuits, determination of misrepresentation, liabilities determination and exemption, joint tort liability and calculation of loss. As defined in the Provisions, misrepresentation can include fraudulent records, misleading statements, material omissions and improper disclosure. The Provisions deal only with misrepresentation made by public companies and not share price manipulation or insider trading.

24 Binglan Xu, "Securities legislation protects investors," China Daily, 28 February 2005, http://www. chinadaily.com.cn/english/doc/2005-02/28/content_419958.htm. "In 2003, the Supreme People's Court promulgated a set of guidelines on [class actions], which said the local courts can only accept cases about fabricated statements, which basically ruled out investors' chances for taking listed companies to court for other misbehaviour."

25 "Zuigao renmin fayuan guanyu shenli zhengquan shichang yin xujia chenshu yinfade minshi peichang anjian de ruogan guiding" ("Several provisions on civil compensation cases arising from misrepresentation in the securities market"), 26 December 2002, available at http://xinhuanet.org.

26 "Zuigao renmin fayuan guanyu shouli zhengzhuan shichang yin xujia chenshu yinfa de minshi qinfan jiufen anjian youguan wenti de tongzhi" ("Notice on questions concerning the acceptance of civil tort dispute cases arising from misrepresentation in the securities market"), Fazhi ribao (Legal Daily), 16 January 2002. 
The greatest criticism of the Provisions is that they require the Ministry of Finance, the CSRC or other administrative agencies first to determine an administrative penalty declaring that directors, officers or other corporate actors have misbehaved. Once this decision is issued by the appropriate administrative agency the courts are then empowered to take the civil case. As a result, obtaining a civil remedy is so cumbersome that private enforcement may be all but impossible.

\section{Recent Amendments to the Company Law}

The dilemma in Chinese company law, as in corporate law around the world, is that a majority shareholder or majority of the shareholders have the power to control a company. Corporate law has long recognized the need to counter this right so that majority shareholders do not exercise their control to gain disproportionate benefits at the expense of the corporation or non-controlling shareholders. ${ }^{27}$ At the same time, opportunistic behaviour by minority shareholders must also be checked. Therefore, corporate law seeks to provide a sensible balance between the control rights of majority shareholders and protecting minority shareholders from abuse. ${ }^{28}$

\section{Protection of shareholders' rights}

The recently amended Company Law makes some considerable progress in this direction but still falls short of protecting minority shareholders in some important respects. This is partly the result of the relatively brief corporate history of post-Mao China: companies are few and only very recently established; most public companies' shares are highly concentrated and have a controlling shareholder (or joint controlling shareholders) ${ }^{29}$; the board of directors is controlled by majority shareholders; PRC courts are inexperienced, ineffective and often corrupt; and market and cultural constraints on the controlling shareholders are weak or absent. ${ }^{30}$ Most importantly - and not surprisingly - the managers, directors and controlling shareholders of these new companies remain sheltered with the power of the state, since in most cases these companies are reformulated SOEs or parts thereof. If corporate law reform is to have the transformational effect on Chinese society for which some reformers hope, these features will have to change.

27 See e.g. James Cox, Thomas Hazen and F. Hodge O’Neal, Corporations (New York: Aspen Law \& Business, 1997), pp. 250-58.

28 Bernard Black and Reinier Kraakman, "A self-enforcing model of corporate law," Harvard Law Review, Vol. 109, No. 8 (1996) pp. 1911-82.

29 In June 2004, CSRC statistics stated that China had 1,324 listed companies. Of those, one shareholder held more than $50 \%$ of the issued shares of 486 companies, and one shareholder held between 20 and $50 \%$ of 724 companies. Nicholas C. Howson, "Regulation of companies with publicly listed share capital in the People's Republic of China," Cornell International Law Journal, Vol. 38, No. 1 (2005) pp. $237-49$.

30 Xiaonian $\mathrm{Xu}$ and Yan Wang, "Ownership structure and corporate governance in Chinese stock companies," China Economic Review, Vol. 10, No. 1 (1999) pp. 75-98. 
Improved corporate governance is a goal of several adjustments in the new Company Law. In general, the revised Company Law creates better rules about shareholders' meetings; it regulates related-party transactions; it provides minority shareholders with some remedies if they are abused; it ensures information rights for minority shareholders; and it reinforces the power of the board of supervisors or other supervisory authorities. Despite these achievements, the revised Company Law also has several failings. Some are continuing lapses and gaps; others are missed opportunities to remedy deficiencies noted in the earlier Company Law. Some of these are detrimental to the protection of the minority shareholders; others do not improve the lot of the majority who control the company.

Article 20 establishes the fiduciary duty ${ }^{31}$ owed by the majority shareholders to the minority shareholders by providing a cause of action for the minority shareholders against controlling shareholders. It provides: "Where any of the shareholders of a company causes any loss to the company or to other shareholders by abusing shareholder's rights, it shall be liable for compensation." These fiduciary duties are owed to all shareholders; elsewhere, Article 152 allows any shareholder "to bring a suit against any person [including controlling shareholders] who encroaches on the lawful rights and interests of the company and causes losses to the company." Despite a failure to list in the new law what acts constitute "encroachment," it provides both a standard and a legal basis for explicit rights to sue, a conspicuous failing of the earlier law which was even more ambiguous as to whether such a right even existed.

The new Company Law also imposes "duties of loyalty and diligence" upon directors, supervisors and senior managers. Article 149 of the revised law prohibits specific acts, mainly involving self-dealing and the usurpation of corporate opportunities as well as ordinary misappropriation, classic duty-ofloyalty problems. These fiduciary principles are alternatives to precatory language or more specific regulatory monitoring. They also shift from criminal and administrative penalties to the private enforcement (by other shareholders) model found in the United States and other developed countries. They substitute deterrence for prior supervision, resetting the balance between majority and minority shareholders.

\section{Equitable treatment for all shareholders}

The revised Company Law seeks to ensure that there are regular shareholders' meetings. Chinese experience has shown that scheduled regular and ad hoc interim meetings can be very useful devices to constrain the board of directors and managers. The original Company Law stipulated that the shareholders'

31 A fiduciary is held to a standard of conduct above that of a stranger or casual business person and must avoid "self-dealing" or "conflicts of interests" where his potential benefit conflicts with what is best for the person who trusts him. Commonly as a legal matter, these are duties of care and loyalty on the part of the fiduciary. 
meeting could only be convened by the board of directors and had to be presided over by the chairman of the board of directors. ${ }^{32}$ Majority shareholders could refuse to convene or to preside over a meeting to suppress expressions of dissent by minority shareholders. Articles 41 and 102 of the revised Company Law entitle the shareholders above a certain threshold, when the board of directors and board of supervisors do not convene or preside over an interim meeting, to do so themselves. Because an interim meeting convened by other shareholders may affect the majority shareholders adversely, this new rule creates in effect a "demand provision" for the board of directors chosen by majority vote to convene shareholders' meetings or else face the prospect that others might convene one. ${ }^{33}$ Article 22 further provides shareholders the right to petition a court to revoke any shareholder or board resolution within 60 days of the resolution's passage, where the procedure for convening that shareholders' meeting violates any law, administrative regulation or the articles of association. So both majority and minority shareholders have an incentive to hold shareholders' meetings in an orderly, predictable and lawful fashion, to avoid unnecessary disputes. ${ }^{34}$ In a shareholders' meeting with all parties present, each party wishing to pass a proposal must create mutually acceptable conditions, conducive to a sensible balance between them.

By providing minority shareholders above certain thresholds with the rights to propose an interim meeting ${ }^{35}$ and with proposal rights, ${ }^{36}$ the revised Company Law may encourage minority shareholders to use the shareholders' meeting to check the illegitimate behaviour of a dominant majority.

The revised law allows shareholders to bring an action against the directors, supervisors or officers of a company for both work-related and non-workrelated acts harmful to the company committed in violation of the articles of association, regulations or laws. Shareholders may also bring an action against third parties whose actions damage the interests of the company. Furthermore, the rules provide the means for minority shareholders to oust directors who

32 The 1994 Company Law of China, Articles 10(1) and 43(3).

33 In most legal systems, company law requires that before shareholders can sue derivatively or on their own behalf they must make an explicit written demand that the board of directors take appropriate legal action to safeguard the corporation's and shareholders' interests. The demand may be excused if to do so would be futile.

34 Stephen Green and Ming He, "China's stock market: out of the valley in 2004?" Royal Institute of International Affairs, Briefing Paper No. 1, February 2004.

35 Article 40 reduces the threshold from $25 \%$ to $10 \%$ of voting rights to call a special meeting in a close corporation. Article 101 further enables the articles of association of a company to specify the requirements for calling a special meeting of a public company. Articles 41 and 102 designate that in case the board of directors and board of supervisors does not convene or preside over the shareholders' meeting, any shareholder possessing $10 \%$ or more voting rights and the shareholders separately or aggregately holding $10 \%$ of the shares can do so.

36 Article 103(2): The shareholders separately or aggregately holding 3\% or more of the shares of the company may put forward a written interim proposal to the board of directors ten days before a shareholders' meeting is held. The board of directors may notify other shareholders within two days and submit the interim proposal to the shareholders' meeting for deliberation. The contents of an interim proposal shall fall within the scope to be decided by the shareholders' meeting, and the interim proposal shall have a clear topic for discussion and matters to be decided. 
injure overall company rights by favouring the majority, helpful in creating a disincentive for majority shareholders' abuse of their power.

The proposal rights give minority shareholders the chance to raise their concerns in the shareholders' meeting, ${ }^{37}$ without which the agenda and content of the shareholders' meeting might be completely controlled by board of directors. As with the rights to propose an interim meeting, the proposal rights also make it possible for outsiders to acquire some shares and replace directors without having to wait until the directors' tenure expires at the next annual shareholders' meeting, reducing the costs of acquisition and creating market power constraints.

Enabling public companies to adopt cumulative voting, set out in Article 106, provides another important protection for shareholders. Under a straight voting system, any person or bloc who controls a majority of the votes in a particular election can elect all the directors. Cumulative voting allows shareholders to multiply their votes by the number of directors and supervisors to be elected. ${ }^{38}$ Furthermore, where a listed company within one year purchases or sells material assets or provides a guarantee in excess of 30 per cent of its total assets, approval of shareholders with no less than two-thirds of voting rights must be obtained. These revised voting rights provide shareholders with large minority stakes a chance to elect at least one or more directors, to affect board and management decisions, and may lead to better corporate governance.

This ability to elect "representative" directors is particularly important in China. There have been many cases where majority shareholders overrode minority shareholders' interests notwithstanding a board with independent directors, the oversight of the board of supervisors and shareholder rights to sue. The root failures lie in the weakness and lack of independence of the judiciary and the high costs of shareholders' suits. ${ }^{39}$ Furthermore, independent directors and supervisors are not in the position of shareholders: they have no motivation to supervise a majority-dominated company. ${ }^{40}$ In contrast, the directors elected by cumulative voting who represent the minority shareholders have greater incentives to exercise their rights. Minority representation on the board may add independent, critical scrutiny of majority-dominated companies and sometimes presents a prior constraint on illegal behaviour, enhancing the protection of minority shareholders.

37 Frank Easterbrook and Daniel Fischel, "Voting in corporate law," Journal of Law \& Economics, Vol. 26 (1983) pp. 395-427.

38 Cumulative voting helps strengthen the ability of minority shareholders to elect a director, allowing shareholders to cast all their votes for a single nominee for the board of directors when the company has multiple openings on its board. For example, if an election is for four directors and a shareholder holds 500 shares (one vote per share), under straight voting they have a maximum of 500 shares for any one candidate (2,000 votes total, 500 votes for each of the four candidates). With cumulative voting, all 2,000 votes could be for one candidate, 1,000 each to two candidates, or otherwise divided whichever way they chose.

39 The minority shareholders need to bear costs of the suit, and have the burden of proof, as a matter of Chinese civil procedure.

40 See Armen Alchian and Harold Demsetz, "Production, information costs, and economic organization," American Economic Review, Vol. 62, No. 5 (1972), pp. 777-95. 
Regulation of related-party transactions ${ }^{41}$ provides protection from the risk that a corporation may be treated unfairly in such transactions. ${ }^{42}$ Legislators cannot expect self-interested directors, for example, to afford primacy to other shareholders' interests. ${ }^{43}$ In recent years, many Chinese companies, especially listed companies, have provided illegal guarantees. Article 16 requires that guarantees or investing by a company in related entities must be subject to the determination of the shareholders' meeting, in which the related parties are not eligible to vote.

Normally the majority shareholders hold a high percentage of voting rights; minority shareholders (due to rational apathy) fail to vote; and there is no minimum quorum for a shareholders' meeting of a public company. Thus, even though an investment or a guarantee will substantially injure the interests of the company and minority shareholders, the proposal will be passed. Excluding the votes of related parties can prevent the majority shareholders from engaging in misconduct. If majority shareholders want the company to provide a guarantee, they must provide the same conditions as, or more favourable conditions than, the market requires. For similar reasons, Article 125 states directors of listed companies are ineligible to vote on matters in which they have an interest.

Providing these remedies to aggrieved minority shareholders not only serves to compensate them but may also deter misconduct by majority shareholders. At the same time, to guard against minority shareholders' opportunism and possible harassment of the majority, the Company Law stipulates certain requirements for the minority to exercise their rights.

Article 106 allows cumulative voting as a choice for public companies, ${ }^{44}$ but boards of directors will probably continue to be controlled by majority shareholders, allowing continuing injury to a company's interests. Most of the articles of association of the company are determined by the controlling shareholders, and companies may "opt out" of cumulative voting, so majority shareholders can veto a decision in favour of cumulative voting. Some object that cumulative voting may polarize a board and transform it into a contentious group, where constant bickering deflects energies from rational efforts to identify and respond to the corporation's problems and opportunities. ${ }^{45}$ Nevertheless, China has introduced independent directors for listed companies to supervise majority shareholders. ${ }^{46}$ The independent directors may also fight with inside directors, and supervision may lead to arguments. On the other hand, minority and majority shareholders' interests may "converge to a

41 Transactions conducted between related parties are sometimes called "connected transactions" in Chinese parlance.

42 Cox, Hazen and O'Neal, Corporations, pp. 204-15.

43 Huan, "Shareholders' rights in China: an analysis of private equity in former state-owned enterprises," Singapore Academy of Law Journal, Vol. 12 (2000), p. 428.

44 Article 106: When the shareholders' assembly elects directors or supervisors, it may, under the articles of association or resolution of the shareholders' assembly, adopt a cumulative voting system.

45 See Robert Charles Clark, Corporate Law (Boston: Little, Brown 1986), pp. 362-64.

46 See China Securities Regulatory Commission, "Guanyu zai shangshi gongsi jianli duli dongshi zhidu de zhidao yijian" ("Guidelines regarding establishing the rule of independent directors"), 21 August 2001, http://www.cas.cn/html/Dir/2001/08/21/5860.htm. 
significant extent." ${ }^{47}$ Hence, contention within the board is unlikely to lead to bad results. Moreover, empirical and historical evidence from the United States shows that the elimination of cumulative voting in large public firms has reduced shareholder wealth on average. ${ }^{48}$ The benefits brought by cumulative voting will definitely outweigh its costs.

\section{Derivative suits; appraisal rights}

Since those controlling a company are unlikely to authorize it to sue them personally, Article 152 establishes a system of derivative suits. It provides a device by which shareholders may enforce claims of the corporation against managing officers and directors of the corporation, who may be dominated by the majority shareholders. In China, where majority shareholders' illegal behaviour is rampant, ${ }^{49}$ the derivative suit may prove a very useful weapon for minority shareholders to protect their interests and deter majority shareholders' oppressive behaviour. To provide a minimal basis for standing to sue, Article 152 requires that the minority shareholders must hold 1 per cent or more of the total shares of the company for more than 180 days and must make a demand on the company first. The reason for the demand requirement is to re-emphasize the basic principle that the board of directors, not the shareholders, manages the corporation, and to protect the directors or supervisors from harassment by litigious shareholders. ${ }^{50}$

Article 75 entitles the shareholders in close companies to appraisal rights when they vote against a shareholders' meeting resolution concerning matters which seriously affect shareholders' rights or suffer other arguably oppressive behaviour. ${ }^{51}$ These appraisal rights liberalize the rules related to shareholders' approval of fundamental transactions. They may also overcome a requirement for unanimous consent that permits a small minority to block a decision desired by the majority. ${ }^{52}$ It gives the majority the right to control the company, while at

47 See Melvin Eisenberg, "The structure of corporation law," Columbia Law Review, Vol. 89, No. 7 (1989), pp. 1461-1525.

48 See Jeffery Gordon, "Institutions as relational investors: a new look at cumulative voting," Columbia Law Review, Vol. 94, No. 1 (1994), pp. 124-92.

49 Gregory Chow, "Corruption and China's economic reform in the early 21st century," Princeton University CEPS Working Paper No. 116, October 2005, http://www.princeton.edu/ ceps/ workingpapers/116chow.pdf.

50 See Clark, Corporate Law, p. 641. In the United States, the demand requirement, minimum shareholdings and posting of bond as security for the expenses of litigation are all features of shareholder derivative litigation.

51 Article 75: Under any of the following circumstances, a shareholder who votes against the resolution of the shareholders' meeting may request the company to purchase its stock rights at a reasonable price: (1) The company has not distributed any profit to the shareholders for five consecutive years, but it has made profits for five consecutive years and conforms to the profit distribution conditions as prescribed in this Law; (2) The merger, split-up, or transfer of the main properties of the company; (3) When the business term as specified in the articles of association expires or other reasons for dissolution as prescribed in the articles of association occur, the shareholders' meeting makes the company continue existing by adopting a resolution on modifying the articles of association.

52 See Cox, Hazen and O'Neal, Corporations, pp. 595-606. In corporate law, the appraisal remedy typically viewed as a form of protection for minority shareholders - gives shareholders the right to dissent from corporate transactions and to obtain payment for their shares from the corporation. 
the same time creating a means for the dissenting shareholders to exit. These appraisal claims, while enhancing fairness, may siphon cash from the corporation; thus, the Company Law stipulates the dissenting shareholders may only exercise the rights in designated circumstances. ${ }^{53}$

Article $183^{54}$ empowers shareholders to apply for the company's dissolution to a People's Court, so long as they successfully prove that the company is encountering serious operating difficulties which will cause substantial and irreparable losses, ${ }^{55}$ and the problems cannot be solved by any other means. The remedy of involuntary dissolution serves as protection against majority oppression as well as an incentive for the majority shareholders to exercise their control so as to maintain minority confidence. ${ }^{56}$ Since involuntary dissolution may cause hardship to other parties, the Article designates that only in the event of serious deadlock with no other solutions may shareholders invoke the remedy. Moreover, to prevent strike suits, ${ }^{57}$ it permits only shareholders who have 10 per cent or more of the shares outstanding to exercise the rights.

To ensure shareholders' rights to information, Article 34(1) and Article 98 entitle the shareholder to consult and copy the articles of association, minutes of the shareholders' meetings, resolutions of the board of directors, resolutions of the board of supervisors, and financial reports. ${ }^{58}$ Article 151 empowers the shareholders to elicit accurate information from the directors, the senior officials and supervisors. To protect their interests, the shareholders need to ascertain how the majority-controlled directors and officers conduct the company's business. Without access to information, the deterrent effects of shareholder oversight would be reduced. To prevent harassment of management or theft of corporate secrets, Article 34 requires that shareholders in limited liability companies cannot consult the accounting books unless they make a request in writing which states a "proper purpose."

\section{Effective monitoring of management}

The revised Company Law intends to reinforce the power of the board of supervisors. The board of supervisors in China - following the model established in German commercial law and employed in other civil law jurisdictions - was supposed to oversee the work of the board of directors and to provide an

53 See Article 75.

54 Article 183: Where any company meets any serious difficulty in its operations or management so that the interests of the shareholders will face heavy loss if it continues to exist and it cannot be solved by any other means, the shareholders who hold $10 \%$ or more of the voting rights of all the shareholders of the company may plead the people's court to dissolve the company.

55 See Alan Wang, "Redressing the rights of shareholders in corporate fraud," http://www. chinalawandpractice.com/default.asp.

56 See Cox, Hazen and O'Neal, Corporations, pp. 679-89.

57 The purpose of a strike suit, brought by someone who owns very few shares, is to gain a private settlement before going to court that would cost the company less than defending the suit. The suit itself does not benefit the company or other shareholders.

58 Article 98 also entitles shareholders to consult records relating to corporate bonds. 
additional layer of checks on management. In the past, it played little role as a watchdog and fell short of the expectations of investors and legislators. Thus, the new Company Law provides the board of supervisors with more powers to make it work properly.

Articles 54, 55 and 119 - which give the board of supervisors the right of inquiry and the right to hire an accounting firm (with the relevant expenses being born by the company) - enhance the board of supervisors' ability to get information about the company, help the board better understand corporate information, and set priorities for supervision. ${ }^{59}$ Articles 40 and 101 entrust the board of supervisors in close and public companies to propose an interim meeting, and Articles 41 and 102 vest the right to convene a shareholders' meeting in the board of supervisors in the event the board of directors or executive directors fail to do so. These rules make it possible for the board of supervisors to propose, convene and preside over a shareholders' meeting and report what it has found, augmenting the links between it and the shareholders, indirectly increasing the board of supervisors' role as a watchdog, providing greater deterrence to illegal behaviour by the majority and more weapons to protect the minority shareholders.

Nevertheless, the new Company Law has not altered situations where the watchdog functions of the board of supervisors can be stymied. Articles 52 and 118 still require that at least one-third of the board of supervisors must be employee supervisors, elected by employees. Theoretically employee supervisors know the operation better than other supervisors, and are thus better able to supervise the board of directors. In practice, the situation is quite different. ${ }^{60}$ Employee supervisors are more likely to be employees whose salaries and promotion are determined by the directors and managers. While employee supervisors have been successful in Europe (in Germany, for example), Asian nations such as South Korea and Taiwan prohibit employees from being supervisors. This is because of the fear that such supervisors, given the hierarchies of Asian societies, would not be able to exercise their rights neutrally.

In addition, Articles 99 and 104 stipulate that supervisors elected by shareholders should be elected by straight voting in public companies, which may also lead to a majority-controlled board of supervisors. Unlike the supervisors in companies in some other Asian countries (Taiwan, Japan and South Korea) those in the PRC cannot act separately and independently. ${ }^{61}$ Because of majority shareholders' control of the board of supervisors, the board may not meaningfully protect minority shareholders.

59 Under provisions of the US Sarbanes-Oxley legislation, a corporation's audit committee also has the authority to retain independent legal, accounting and other consultants to advise the committee.

60 Articles 52 and 124 of the 1994 Company Law also required that some supervisors be employees, but in public companies there were few employee supervisors who fulfilled their responsibility to protect minority shareholders from oppression.

61 Articles 54, 55, 56, 57,118, 119 and 120 of the Company Law require the supervisors in a company to act collectively, except when attending the meeting of the board of directors. 
Voting rules still provide various loopholes. The revised Company Law does not mandate cumulative voting and the manner of election of auditors for public companies. Minority shareholders sometimes do not vote in their best interests as a result of information asymmetry, collective action problems or difficulty in judging what arrangements will best suit their interests. ${ }^{62}$ Mandatory structural rules may not only help ensure outside directors and large minority shareholders participate in the decision-making process but also protect them against opportunism by insiders. ${ }^{63}$

Article 170 enables a public company to choose the shareholders' meeting or the board of directors to hire or dismiss the accounting firm which audits the company. ${ }^{64}$ Independent auditors play a "gatekeeper" role in protecting minority shareholders' interests. Regrettably, in China, there have been many instances where the independent auditors have "cooked the books," 65 providing further support for the proposition that the watchdogs should not be chosen by those they are supposed to watch. ${ }^{66}$ Indeed, mandating that independent auditors must be chosen by the shareholders' meetings does nothing to prevent majority shareholders' opportunistic amendment of the articles to allow the majority-dominated board of directors to choose the independent auditors. It is hard to imagine how the auditors thus chosen will fulfil their gate-keeping responsibility

Article 152 stipulates that defendants in a derivative suit can only be the directors, senior managers and supervisors of a company. An outsider who adversely affects the company's interests - for instance, one who does not pay a debt to the company on time and is not sued by the directors and the supervisors - cannot be sued by the shareholders. As a result, this rule cannot prohibit majority shareholders from utilizing other companies as intermediaries to transfer interests in public companies.

Some elements of the revised Company Law could harm the company and majority shareholders. Article $151^{67}$ demands that directors, senior managers and supervisors must answer shareholders' enquiries. Yet sometimes honest, complete public responses by a director or supervisor may injure the interests of the company; for example, these may involve trade secrets or business strategy. Despite provisions of the Company Law which might hold shareholders liable,

62 Eisenberg, "The structure of corporation law," p. 1461.

63 Jeffery Gordon, "The mandatory structure of corporate law," Columbia Law Review, Vol. 89, No. 7 (1989) pp. 1549-98.

64 Article 170 enables both close companies and public companies to choose whether the shareholders' meeting or the board of directors determines hiring or dismissing independent auditors.

65 Yuan Ding, Hua Zhang and Honghui Zhu, "Accounting failures in Chinese listed firms: origins and typology," International Journal of Disclosure and Governance, Vol. 2, No. 4, (2005) pp. 395-412. Z. Jun Lin and Feng Chen, "An empirical study of audit 'expectation gap' in the People's Republic of China," International Journal of Auditing, Vol. 8, No. 2 (2004), pp. 93-115.

66 See Clark, Corporate Law, p. 375.

67 Article 151: If the shareholders' meeting or shareholders' assembly demands a director, supervisor or senior manager attend the meeting as a non-voting representative, he shall do so and shall answer shareholders' inquiries. 
the weakness of the courts, the expense of lawsuits and unpredictability of results make any threat of liability highly unlikely. ${ }^{68}$

Articles 34 and 98 give shareholders the right to consult resolutions of meetings of the board of directors, which may also provide access to trade secrets of the company. Minority shareholders may use this right to affect adversely the interests of the company. The Company Law now does not require that shareholders who want to review resolutions of the meetings of the board of directors have a proper purpose.

\section{Executive compensation}

Among the issues related to effective monitoring of management by the board of directors, perhaps the most important is executive compensation. Recently this has become a major issue, not only in the United States but in other developed countries. In the United States it is hardly new; as early as 1939, the SEC enacted regulations regarding disclosure of executive compensation. ${ }^{69}$ Recently, corporate scandals such as those involving Enron, WorldCom, HealthSouth and Tyco have focused on executive compensation as an important factor in eroding corporate governance. The primary complaint against excessive executive compensation is that in many cases - despite the mantra of pay for performance - executive pay simply does not correlate with performance. ${ }^{70}$ The widespread view is that chief executive officers are grossly overpaid ${ }^{71}$ : senior managers' pay has increased significantly faster than that of ordinary workers. ${ }^{72}$ Moreover, the range of perquisites for high-level executives, including bonuses and special payments, has become excessive.

In China, the development of capital markets and increase in the number of large companies had brought new attention to executive compensation. ${ }^{73}$ As in other economies, directors and officers of Chinese companies do not own corporate assets; thus, the economic consequences of their management are felt not by them but by shareholders. To align their interests with those of shareholders and to reduce agency costs, companies create incentives for directors and executives. The most effective, but most often misapplied, incentive is executive compensation. ${ }^{74}$

68 Cindy Schipani and Junhai Liu, "Corporate governance in China: then and now," Columbia Business Law Review, Vol. 2002 (2002), pp. 1-69.

69 Tracy Scott Johnson, "Pay for performance: corporate executive compensation in the 1990s," Delaware Journal of Corporate Law, Vol. 20 (1995), p. 183.

70 Ibid. p. 214.

71 Stephen M. Bainbridge, "Book review essay: executive compensation: who decides? Pay without performance: the unfulfilled promise of executive compensation," Texas Law Review, Vol. 83 (2005), pp. 1615-62.

72 According to the Institute for Policy Studies, the ratio in pay between CEOs covered in Business Week's survey and the average production worker reached 301 to 1 in 2003. In 2002, the ratio stood at 282 to 1. Estimates more recently suggest the ratio is now over 400 to 1. Institute for Policy Studies and United for a Fair Economy, Executive Excess 2004 (2004).

73 Kato and Long, "Executive compensation, firm performance, and corporate governance," pp. 945-83.

74 See e.g. D. Quinn Mills, "Paradigm lost: the imperial CEO," Directors and Boards, Vol. 27, No. 4 (2003), pp. 41-42. 
The revised Chinese Company Law provides that directors, supervisors and management executives must comply with the laws, administrative regulations and corporate charters, and that they owe the duties of loyalty and care. Directors, supervisors and executives may not utilize their power for bribes or other illegal income and may not make personal use of corporate assets. ${ }^{75}$ The law further provides that they and controlling shareholders should compensate the company for any losses resulting from abuse of their control positions. ${ }^{76}$ As noted above, shareholders' right to file derivative suits is recognized by the law; Article 152 of the Company Law entitles shareholders to sue directors and executives for illegal use of corporate assets.

In most American jurisdictions, suits against executives for excessive compensation rarely succeed. Only where plaintiffs can prove that compensation is unreasonable for the services provided will the courts intervene with their equity power to "prevent a waste of the corporation's assets." "77 If equity requires it, the court will award recovery of excess compensation directly to harmed minority shareholders. The provisions of China's revised Company Law do not explicitly allow a parallel action, so it is difficult to determine whether or not Chinese courts can sustain similar claims.

Increased disclosure of executive compensation has become the norm in developed countries in recent years. The United States Congress passed the Sarbanes-Oxley Act in 2002 which, inter alia, prohibits corporate loans to executives. ${ }^{78}$ British and Canadian laws also impose some restrictions on executive compensation; for example, a British corporate reform regulation also passed in 2002 requires an annual shareholder vote on executive compensation practices. $^{79}$

Compared with the law in North America and the United Kingdom, Chinese law has much room for development. Despite China's traditions of centralization and government regulation, the law hardly regulates executive compensation at all. The Company Law treats it entirely as an internal corporate issue, only providing that compensation of directors and supervisors shall be decided by the shareholders' meeting ${ }^{80}$ and that compensation of executives shall be decided by the board of directors. ${ }^{81}$ After recent revisions, the law prohibits companies from offering loans directly or indirectly through subsidiaries to

75 Article 148

76 Article 21.

77 Such lawsuits were successfully prosecuted in the Tyco case. Yet courts often uphold huge compensation for executives. See In re The Walt Disney Co. Derivative Litigation, Delaware No 411, 2005 (8 June 2006), where the Delaware Supreme Court upheld a severance package of \$130 million after only 14 months' work for Michael Ovitz, which withstood a shareholder challenge, In re The Walt Disney Co. Derivative. Litigation, Delaware No. 15452 (9 August 2005) (Chandler, C.).

78 Sean A. Power, "Comment, Sarbanes-Oxley ends corporate lending to insiders: some interpretive issues for executive compensation surrounding the Section 402 loan prohibition," University of Missouri Kansas City Law Review, Vol. 71 (2003), p. 911.

79 Joanna L. Ossinger, "Regarding CEO pay, why are the British so different?" Wall Street Journal, 10 April 2006.

80 Article 37 (2).

81 Article 46 (9). 
directors, supervisors and executives. ${ }^{82}$ It also requires that companies disclose the compensation of directors, supervisors and executives regularly, similar to provisions of the US Sarbanes-Oxley Act. $^{83}$ Yet there have been no implementing rules promulgated by the State Council, the CSRC or other relevant government agencies. It is clear that the system for regulating executive compensation in China will have to be improved in the future, as incentive systems are adopted which attempt to tie managers' take-home pay with job performance. While excessive executive compensation in Chinese listed companies has not proven to be a major problem thus far, experience elsewhere makes clear the need for government regulation of executive compensation to protect vulnerable shareholders - especially small shareholders. ${ }^{84}$ Such reforms should do much to increase public confidence in corporate governance and the capital market in China.

\section{Conclusion}

Although they fail to address all concerns, the revised Company Law and Securities Law do endeavour to stipulate better rules by taking account of the actual situation of corporate governance in PRC and making use of foreign legislative experience. As for balancing the interests of majority and minority shareholders, especially in attempting to enhance the protection of minority shareholder's interests, the new laws do make some progress. It remains to be seen how effective they will turn out to be in practice.

In the long term, better corporate governance in China will require: clear rules and regulations, including implementing rules for these new laws; certainty in the application of these rules and regulations; fair and consistent enforcement, combined with strong sanction against breaches; and policy initiatives to coordinate reforms necessitated by market developments. Not every observer necessarily applauds the recent trends in China of adopting foreign models of corporate governance to achieve results in the context of the business culture of Chinese enterprises. ${ }^{85}$ It remains to be seen how a more characteristically Chinese corporate governance system might evolve.

Moreover, there may be many twists and turns in the process of improving and adjusting the corporate governance regime in China. For example, in 2004

82 Article 116.

83 Article 117.

84 But see Dapeng Cai and Jie Li, "A theoretical investigation of agent corruption in Chinese SOEs: causes, effects, and its prevention," taweb.aichi-u.ac.jp/kurihara/jsie8ab.pdf. The authors find increasingly pervasive corruption by SOE managers, especially in large and medium-sized SOEs which have begun to access global capital markets. Others suggest that Chinese managers may need different incentives, such as stock options (which are rarely granted in China), as an inducement to better corporate governance. See Rui, Firth and Fung, "Corporate governance and CEO compensation," p. 20.

85 See e.g. Yu Guanghua, "Takeovers in China: the case against uniformity in corporate governance," Common Law World Review, Vol. 34, No. 2 (2005) pp. 169-98. Hui Huang, "The regulation of insider trading in China: a critical review and proposals for reform," Australian Journal of Corporate Law, Vol. 17 (2005), pp. 281-322. 
the contentious issue of management buyouts (MBOs) of SOEs was clarified. New State Asset Supervision and Administration Commission (SASAC) regulations temporarily prohibited MBOs at large SOEs, closed a number of loopholes and clarified under which conditions MBOs of smaller enterprises could be carried out. ${ }^{86}$ At the time, fears were expressed about the possible abuse of insider information by managers to acquire shares of SOEs at bargain prices. By 2006, however, the government was promising to introduce a stock option scheme for managers at China's overseas-listed SOEs, which analysts then said would be an important step in promoting the healthy growth of Chinese companies in the long run. A management incentive stock option programme for overseas-listed SOEs, drafted by SASAC, was to take effect from 1 March $2006 .{ }^{87}$ SASAC relaxed the previous ban on management buyouts in large-scale SOEs, allowing executives in those companies to purchase limited shares of the company in which they work. The relationship between policy experimentation and law reform remains unclear and suggests that transition from the command economy to a market environment will combine legal, economic and policy reforms in unstable combinations until a new model suited to Chinese circumstances is developed.

86 Barry Naughton, "SASAC rising," China Leadership Monitor, No. 14 (2005), Hoover Institution, http://www.chinaleadershipmonitor.org/20052/bn.html.

87 Zheng Lifei, "State firm executives to get stock options from March 1," China Daily, 23 February 2006. "The application of (the management stock options incentive) scheme in overseas-listed SOEs is an important step to improve their corporate governance," said Wang Zhigang, director of the Company Reform and Development Studies at a think-tank affiliated to SASAC. 